\title{
Evaluation of Anti-Malarial Effect of Moringa oleifera (Lam) in Plasmodium yoelii Infected Mice
}

\author{
MEGHA SHRIVASTAVA*, ARTI PRASAD ${ }^{1}$ AND D. KUMAR ${ }^{1}$ \\ Department of Zoology, Government PG College Guna, Madhya Pradesh 473001, ${ }^{1}$ Department of Zoology, University College \\ of Science, Mohanlal Sukhadia University, Udaipur, Rajasthan 313001, India
}

Shrivastava et al.: Moringa oleifera (Lam.) as an Antimalarial

\begin{abstract}
Malaria kills a lot of people every year in the world, yet this has been observed with little progress in controlling this disease. Moreover, the number of cases is increasing, resulting from the rise of drugresistant parasites and insecticide-resistant mosquitoes. In the present study the antimalarial efficiency of flowers and leaves of the Moringa oleifera (Lam.) plant was evaluated against rodent malaria parasite: Plasmodium yoelii (Chloroquine resistant N-67 strain) infected Swiss albino mice. For the study, crude extracts of flowers and leaves of the Moringa oleifera (Lam.) plant were given at different doses i.e., 125, 250, 500 and $1000 \mathrm{mg} / \mathrm{kg}$ to Plasmodium yoelii infected Swiss albino mice, then various parameters llike percent of suppression of parasites, haematological parameters, survival time and body weight of mice, were determined. Percent of suppression of parasites were evaluated by observing Giemsa stained blood smears, which were prepared from different treated groups of experimental mice and haematological testing was done with an automated haematological analyser. The percent of suppression exerted by the flower and leaf against Plasmodium yoelii count ranged between 59 to $41 \%$ and 56 to $32 \%$, respectively. Both extracts were found to give positive results as they prevented the major changes in haematological parameters i.e., count of red blood cells, white blood cells and platelets, haemoglobin concentration and haematocrit value which occurred due to Plasmodium infection. Maximum antimalarial effect was observed with the highest dose of the flower extract at $1000 \mathrm{mg} / \mathrm{kg}$ followed by leaf extract at the same dose. The crude extract prolongs the survival time of mice as well as prevents body weight loss compared to negative control groups. The results are collectively indicated that the Moringa oleifera (Lam.) plant has a promising anti plasmodial activity against Plasmodium yoelii. Thus, it might be considered as a potential source for the development of novel antimalarial agents.
\end{abstract}

Key words: Malaria, Plasmodium, plant, extract, blood, Moringa oleifera

Malaria is one of the most serious as well as widespread disease and also becoming more complicated due to the emergence of drug resistance in parasites. In many countries it has been observed that where Plasmodium falciparum is endemic, drug resistance is in prominent condition. Due to the above reason in such countries, unavailability of effective and affordable drugs is becoming a major problem. Hence there is an urgent need for a novel effective antimalarial treatment. Medicinal plants have been proved as a potential target for research and development in alternative antimalarial drugs with novel modes of action. Therefore, it becomes very important to explore nature systematically for the benefit of mankind.

Moringa oleifera ( $M$. oleifera) belongs to the Moringaceae family and commonly known as

*Address for correspondence

E-mail: meghapatan@gmail.com

November-December 2021 'drumstick or 'horseradish tree'. This plant grows throughout tropical and native parts of sub-Himalayan tracts including north-west India, Pakistan, Bangladesh and Afghanistan ${ }^{[1]}$. The above plant has a very high nutrition value and impressive range of medical properties. Various parts of the above plant like- flower, leaf, seed, root, bark and fruit are used medically in different health problems such as cardiac and circulatory disease, cancer, inflammation, parasitic disease, bacterial infection and fungal disease. And are

This is an open access article distributed under the terms of the Creative Commons Attribution-NonCommercial-ShareAlike 3.0 License, which allows others to remix, tweak, and build upon the work non-commercially, as long as the author is credited and the new creations are licensed under the identical terms

Accepted 01 September 2021

Revised 10 April 2021

Received 21 October 2020

Indian J Pharm Sci 2021;83(6):1221-1228 
also being used for the treatment of various disorders with in the indigenous system of medicine ${ }^{[2]}$. The aim of this study is to evaluate the antimalarial properties of M. oleifera flower and leaf extract in Plasmodium yoelii (P. yoelii) infected mice.

\section{MATERIALS AND METHODS}

\section{Plant collection and extract preparation:}

Various parts i.e., leaves and flowers of $M$. oleifera plant were collected from Udaipur district, Rajasthan, India. Powder forms were prepared after the drying process of the plant parts at room temperature. Further, crude extracts were prepared with the help of Soxhlet apparatus in methanol solution for both flower and leaf separately. Then the evaporation process was carried out for the complete dryness of the extracts at room temperature, finally residues were obtained, weighed and stored at $4^{\circ}$.

\section{Experimental animals and parasite strain:}

For the experimental studies, Laboratory reared Swiss albino mice of both sex with approximate weight of 22 to $26 \mathrm{gm}$. and age of 5-7 w were used and kept in polypropylene cages in groups of 5-6 animals/cage under standard conditions of temperature $22 \pm 2^{\circ}$ and humidity (40-60\%) in animal house and given commercially available pellet diet supplemented with soaked grains. They were exposed by the 12:12 dark-to-light cycle. The protocols of the assessment of antimalarial activity on Swiss albino mice were approved by the Institutional Animal Ethical Committee of the University (No. CS/ Res/07/759).

Chloroquine sensitive $P$. yoelii (Strain N-67) was used for antimalarial testing, which was obtained from Central Drug Research Institute (CDRI) Lucknow UP, India. These parasites were maintained in the laboratory via a serial passaging process within mice groups.

\section{Toxicity assessment and dose selection:}

Before the testing of antimalarial property, toxicity assessment of $M$. oleifera flower and leaf was carried out for the evaluation of its toxic effect on the mice. Toxicity assessments of these extracts were performed in the non-infected Swiss albino mice for their sub-acute toxicity. For this, each extract was tested separately with the help of similar protocols and given orally for $4 \mathrm{~d}(\mathrm{~d} 0$ to $\mathrm{d} 3)$ with the help of gavages ${ }^{[3]}$.

The mice were randomly divided into 7 groups, having six mice (as replica) per group. The mice of Group 1 (as control group) received $0.5 \mathrm{ml}$ of Distilled Water $\left(\mathrm{dH}_{2} \mathrm{O}\right)$. Group 2, to Group 4 were received flower extract whereas Group 5 to Group 7 received leaf extract for $4 \mathrm{~d}$ continuously via oral method with a single dose volume $(0.5 \mathrm{ml})$ at the dose level of 1000,2000 and $3000 \mathrm{mg} / \mathrm{kg}$ body weight, respectively. All the experimental animals were kept under observation for $14 \mathrm{~d}$ for gross changes such as weight, loss of appetite, hair erection, tremors, lacrimation, convulsions, salivation, diarrhoea, mortality and other symptoms of toxicity.

For the assessment of sub-acute toxicity, haematological parameters (i.e., Red Blood Cells (RBC), White Blood Cells (WBC) and platelet count, haemoglobin concentration and haematocrit value) were determined before (atd 0 ) and after (at 4 ) the administration of crude extract. On the basis of sub-acute toxicity assessment, four dose levels $(125 \mathrm{mg} / \mathrm{kg}, 250 \mathrm{mg} / \mathrm{kg}, 500 \mathrm{mg} / \mathrm{kg}$, $1000 \mathrm{mg} / \mathrm{kg}$ ) were decided for the assessment of anti plasmodial activity of both extracts ${ }^{[3]}$.

\section{Evaluation of anti-plasmodium Activity:}

Parasite Inoculation: All experimental mice were inoculated with $P$. yoelii infected blood which was collected from previously infected mice. Blood collection was carried out in Ethylenediaminetetraacetic Acid (EDTA)-coated tubes followed by dilution with normal saline to make final suspension containing aliquot $1 \times 10^{6}$ parasitized RBCs in $0.5 \mathrm{ml}$. Each mouse was injected intraperitoneally with $0.5 \mathrm{ml}$ of infected blood containing approximately $1 \times 10^{6}$ parasitized RBCs.

Grouping and dosing of mice: After the assessment of the toxicity effect of both extracts, anti-plasmodium assessments were carried out with selected doses $(125 \mathrm{mg} / \mathrm{kg}, 250 \mathrm{mg} / \mathrm{kg}, 500 \mathrm{mg} / \mathrm{kg}, 1000 \mathrm{mg} / \mathrm{kg})$ against $P$. yoelii infected mice.

$P$. yoelii infected mice were divided randomly into ten groups (six mice per group). Group 3 to Group 6 were administered with $M$. oliefera flower extract at the dose level of $125,250,500,1000 \mathrm{mg} / \mathrm{kg}$ body weight per day, respectively, whereas Group 7 to Group 10 were administered with $M$. oliefera leaf extract at the dose level of $125,250,500,1000 \mathrm{mg} / \mathrm{kg}$ body weight per day, respectively. Group 1 and 2 were considered as control groups, where Group 1 mice were treated with Artemether $(1.25 \mathrm{mg} / \mathrm{kg} / \mathrm{d})$ to serve as positive control and Group 2 mice were kept untreated with only 
distilled water as negative control. All the doses were given through oral route with gavages.

$4 \mathrm{~d}$ suppressive test: Anti-plasmodium activity of both plant extracts were carried out by $4 \mathrm{~d}$ suppressive test with the standard protocols ${ }^{[4,5]}$. On d 0 (i.e., the day of infection) after $3 \mathrm{~h}$ of infection, the above dosing protocols were followed for all groups of mice for $4 \mathrm{~d}$ continuously (from d 0 to $\mathrm{d} 3$ ). On the $\mathrm{d} 4$ and $\mathrm{d} 10$, thin blood smears were prepared via collecting blood from the tail region of each mouse.

Determination of parasitemia: Blood smears which were prepared on $\mathrm{d} 4$ and $\mathrm{d} 10$ were examined for the determination of percent parasitemia. All blood smears were fixed in absolute methanol in the first step followed by a staining process with Giesma stain at $\mathrm{pH} 7$ for $25 \mathrm{~min}$. Further slides were examined microscopically with 100x magnification for the calculation of percent parasitemia by counting the number of parasites with observation of 10 to 50 fields as below.

Percent parasitemia $=$ Number of parasitized red cells counted/Number of total red cells counted $\times 100$

Further, the percent of suppression was calculated using the flowing formula:

Percent of suppression=Parasitemia in negetive control group-Parasitemia in treated group/Parasitemia in negetive control group $\times 100$

\section{Determination of haematological changes:}

During the $4 \mathrm{~d}$ suppressive test haematological changes were also observed. For this, blood samples of all group experimental animals were collected into EDTAcoated tubes from the tail region of mice at $\mathrm{d} 0$ (before infection) and $\mathrm{d} 4$ of experiment to determine percent changes in blood parameters due to Plasmodium infection and effect of plant extract. Haematological assessment was done by considering following blood parameters: Total count of $\mathrm{RBC}, \mathrm{WBC}$ and platelets, haemoglobin concentration and haematocrit value with the help of Automatic Haematology Analyser.

\section{Data analysis:}

Finally, data was analysed statistically using Graph Pad Prism software. The differences between means of measured parasitemia, haematological changes, survival time of mice and body weight changes were compared using one way Analysis of Variance (ANOVA) test and followed by Dunnett's multiple comparisons test. The $\mathrm{p}<0.05$ were observed as statistically significant.

\section{RESULTS AND DISCUSSION}

Results of sub-acute toxicity assessment indicated that both (flower and leaf) extracts were not found toxic for the experimental mice even at the highest dose level $(3000 \mathrm{mg} / \mathrm{kg})$, within the first $24 \mathrm{~h}$ as well as for the following $14 \mathrm{~d}$ of experiment. Similarly, their physical and behavioural observations also have not shown any visible signs of toxicity like: lacrimation, tremors, loss of appetite, hair erection, salivation and diarrhoea. Along with changes in above haematological parameters were also found statistically non-significant.

The value of the percent of suppression was found significant statistically $(p<0.05)$ for each dose level of both plant extracts. The flower and leaf extracts of $M$. oleifera produced a dose dependent suppression in parasite at the different doses $(125,250,500,1000 \mathrm{mg} /$ $\mathrm{kg}$ ) against $P$. yoelii (N-67 strain) infected Swiss albino mice. At the lower dose level $(125 \mathrm{mg} / \mathrm{kg})$, the values of percent of suppression were found $40.74 \%$ and $20.36 \%$ for flower extract whereas $31.85 \%$ and $14.75 \%$ for leaf extract ond 4 and $\mathrm{d} 10$ of experiment, respectively but at the highest dose level $(1000 \mathrm{mg} / \mathrm{kg})$, the percent of suppression values were increased with $58.52 \%$ and $43.75 \%$ for flower extract and $56.30 \%$ and $36.90 \%$ for leaf extract. If we compare the percent of suppression with the positive control group (Group I) which was treated by the Artemether, it showed $89.63 \%$ and $77.54 \%$ suppression on $\mathrm{d} 4$ and $\mathrm{d} 10$ respectively (Table 1 and fig. 1)

Flower and leaf extracts of $M$. oleifera prevented the haematological changes in a dose dependent manner as compared to the negative control group. Haematological values on $\mathrm{d} 4$ indicated that both extracts of $M$. oleifera prevented the reduction of $\mathrm{RBC}$, haemoglobin, haematocrit value and platelets significantly $(p<0.05)$ whereas increased the number of WBC at all dose levels (125 mg, 250mg, $500 \mathrm{mg}$ and $1000 \mathrm{mg}$ ) as compared to negative control group. Maximum protection was found with $1000 \mathrm{mg} / \mathrm{kg}$ treatment of flower extract with the percent change of RBC $(-6.33 \%)$, haemoglobin $(-2.07 \%)$, haematocrit value $(-1.87 \%)$, platelets $(-14.17 \%)$ and WBC (+9.21\%) on d 4 (Table 2 and Table 3).

The result of mean survival time of experimental mice at highest dose level $(1000 \mathrm{mg} / \mathrm{kg})$ was $15.25 \pm 0.16 \mathrm{~d}$ for flower and $14.36 \pm 0.23 \mathrm{~d}$ for leaf extract whereas in case of positive control (Artemether treated group) it was $25 \pm 1.39 \mathrm{~d}$ (Table 1$)$. 
TABLE 1: CHEMO-SUPPRESSIVE EFFECT OF M. Oleifera (Lam.) CRUDE EXTRACT ON PARASITAEMIA LEVEL OF $P$. yoelii INFECTED SWISS ALBINO MICE

\begin{tabular}{lcccccc}
\hline Treatment & $\begin{array}{c}\text { Dose } \\
(\mathbf{m g} / \mathbf{k g} / 0.5 \mathrm{ml} \text { of water })\end{array}$ & \multicolumn{2}{c}{$\begin{array}{c}\text { Percent parasitaemia } \\
(\%)\end{array}$} & \multicolumn{2}{c}{$\begin{array}{c}\text { Percent of } \\
\text { suppression }\end{array}$} & $\begin{array}{c}\text { Survival time } \\
(\text { mean } \pm \text { SD) Days }\end{array}$ \\
\hline & & $\mathrm{d} 4$ & $\mathrm{~d} 10$ & $\mathrm{~d} 4$ & $\mathrm{~d} 10$ & \\
$\mathrm{dH}_{2} \mathrm{O}(\mathrm{NC})$ & -- & $1.35 \pm 0.07$ & $35.66 \pm 1.31$ & 0 & 0 & $10.50 \pm 0.64$ \\
Artemether & 1.25 & $0.14 \pm 0.01$ & $8.01 \pm 0.49$ & 89.63 & 77.54 & $25.00 \pm 1.39$ \\
$(\mathrm{PC})$ & 125 & $0.80 \pm 0.16$ & $28.4 \pm 1.88$ & 40.74 & 20.36 & $12.22 \pm 0.14$ \\
$\mathrm{MF}$ & 250 & $0.69 \pm 0.14$ & $26.3 \pm 1.87$ & 48.89 & 26.25 & $14.60 \pm 1.90$ \\
& 500 & $0.60 \pm 0.14$ & $23.52 \pm 1.76$ & 55.56 & 34.04 & $14.90 \pm 0.57$ \\
& 1000 & $0.56 \pm 0.07$ & $20.06 \pm 1.56$ & 58.52 & 43.75 & $15.25 \pm 0.16$ \\
& 125 & $0.92 \pm 0.18$ & $30.40 \pm 1.67$ & 31.85 & 14.75 & $10.68 \pm 0.38$ \\
$\mathrm{ML}$ & 250 & $0.74 \pm 0.13$ & $29.30 \pm 1.29$ & 45.19 & 17.84 & $12.10 \pm 0.64$ \\
& 500 & $0.62 \pm 0.11$ & $24.95 \pm 1.66$ & 54.07 & 30.03 & $13.70 \pm 1.91$ \\
& 1000 & $0.59 \pm 0.08$ & $22.50 \pm 1.46$ & 56.30 & 36.90 & $14.36 \pm 0.23$ \\
\hline
\end{tabular}

Note: NC-Negative control; PC-Positive control; MF-M. oleifera flower; ML: M. oleifera leaf

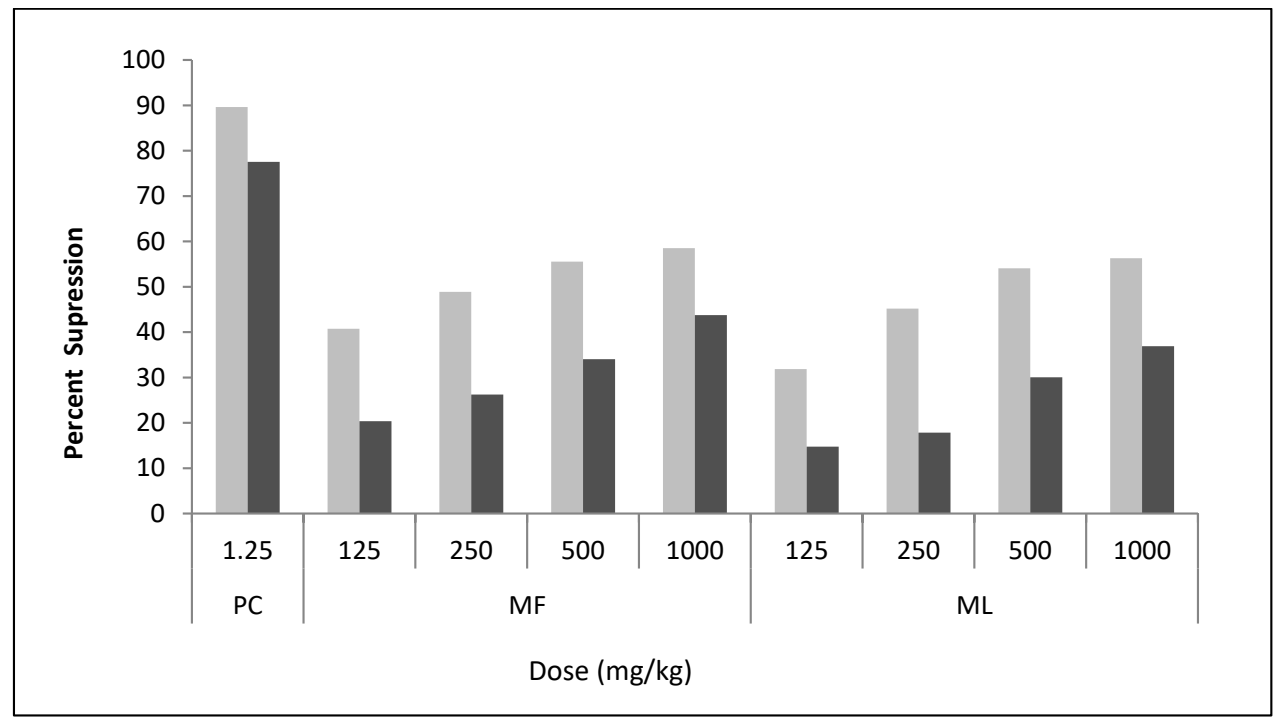

Fig. 1: Chemo-suppressive effect of $M$. oleifera (Lam.) crude extract on suppression level of $P$. yoelii infected Swiss albino mice Note: PC-Positive control; MF-M. oleifera flower; ML-M. oleifera leaf; ( $\square$ ) d 4; ( $\square$ ) d 10

Results of $4 \mathrm{~d}$ suppressive test also revealed that all extracts treated groups prevented loss of body weight in mice significantly $(\mathrm{p}<0.05)$ as compared to negative control. At $\mathrm{d} 4$ the percent change in the body weight was $+4.06 \%$ and $+3.76 \%$ for flower and leaf treatment, respectively at the highest dose level $(1000 \mathrm{mg} / \mathrm{kg})$ of both extracts whereas it was found $+0.38 \%$ and $+5.66 \%$ for negative and positive control, respectively (fig. 2).

From several years, plants have been used as a remedy for thousands of diseases throughout the world and are also the basis for many pharmaceuticals currently in use. In the studies of malaria drug discovery, main focus is given to routine screening for erythrocytic (blood) stage of parasite which is relatively inexpensive and easier to carry out as compared to pre-erythrocytic stage investigations and clinically more demanding for the malaria treatment ${ }^{[6]}$. Percent of suppression is an important measurement for the assessment of the efficacy of any given crude extract or antimalarial compound therefore a good antimalarial drug which is given in the accurate dose; leads to quick suppression of the parasite ${ }^{[7]}$. The $4 \mathrm{~d}$ suppressive test is one of the key method for the assessment of antimalarial activities in the rodent model ${ }^{[8,9]}$.

When different formulated doses $(125,250,500$, $1000 \mathrm{mg} / \mathrm{kg}$ ) of both extracts (flower and leaf) were administered to $P$. yoelii infected Swiss albino mice for the assessment of antimalarial properties, it revealed that the antimalarial effect is dose dependent. The 
www.ijpsonline.com

TABLE 2: EFFECT OF $M$. oleifera (Lam.) CRUDE EXTRACT ON WBC, RBC AND HAEMOGLOBIN PARAMETERS OF $P$. yoelii INFECTED SWISS ALBINO MICE

\begin{tabular}{|c|c|c|c|c|c|c|c|c|c|c|}
\hline \multirow{3}{*}{$\begin{array}{l}\text { Treatment } \\
\\
\mathrm{dH}_{2} \mathrm{O} \\
(\mathrm{NC})\end{array}$} & \multirow{3}{*}{$\begin{array}{c}\begin{array}{c}\text { Dose } \\
\text { (mg/ } \\
\mathrm{kg} / 0.5 \\
\mathrm{ml} \text { of } \\
\text { water) }\end{array} \\
\end{array}$} & \multicolumn{2}{|c|}{$\begin{array}{c}\text { WBC } \\
10^{3} / \mu l \\
(\text { mean } \pm S D)\end{array}$} & \multirow{2}{*}{$\begin{array}{c}\% \\
\text { change }\end{array}$} & \multicolumn{2}{|c|}{$\begin{array}{c}\text { RBC } \\
10^{6} / \mu l \\
(\text { mean } \pm S D)\end{array}$} & \multicolumn{2}{|c|}{$\%$ change } & $\begin{array}{c}\text { HGB } \\
\text { g/dl } \\
\text { mean } \pm S D)\end{array}$ & \multirow{2}{*}{$\begin{array}{c}\% \\
\text { change }\end{array}$} \\
\hline & & d 0 & d 4 & & d 0 & d 4 & -- & d 0 & d 4 & \\
\hline & & $19.10 \pm 0.02$ & $24.92 \pm 0.61$ & 30.47 & $10.7 \pm 0.03$ & $8.12 \pm 0.20$ & -24.11 & $14.52 \pm 0.04$ & $11.86 \pm 0.29$ & -18.32 \\
\hline $\begin{array}{l}\text { Artemether } \\
\text { (PC) }\end{array}$ & 1.25 & $18.38 \pm 0.09$ & $19.16 \pm 0.54$ & 4.26 & $10.60 \pm 0.01$ & $10.01 \pm 0.28$ & -1.42 & $14.72 \pm 0.14$ & $14.70 \pm 0.71$ & -0.14 \\
\hline \multirow{4}{*}{ MF } & 125 & $15.5 \pm 0.12$ & $19.05 \pm 0.93$ & 22.9 & $10.01 \pm 0.15$ & $8.46 \pm 0.41$ & -15.48 & $13.10 \pm 0.22$ & $11.90 \pm 0.58$ & -9.16 \\
\hline & 250 & $19.65 \pm 0.11$ & $22.43 \pm 1.24$ & 14.15 & $10.80 \pm 0.19$ & $9.70 \pm 0.53$ & -12.5 & $14.20 \pm 0.15$ & $13.22 \pm 0.73$ & -6.9 \\
\hline & 500 & $14.22 \pm 0.22$ & $15.80 \pm 0.40$ & 11.11 & $10.43 \pm 0.21$ & $9.77 \pm 0.25$ & -10.19 & $14.10 \pm 0.11$ & $13.40 \pm 0.34$ & -4.96 \\
\hline & 1000 & $16.40 \pm 0.28$ & $17.91 \pm 0.45$ & 9.21 & $10.40 \pm 0.22$ & $9.10 \pm 0.23$ & -6.33 & $14.50 \pm 0.22$ & $14.20 \pm 0.36$ & -2.07 \\
\hline \multirow{4}{*}{ ML } & 125 & $15.29 \pm 0.26$ & $18.88 \pm 0.45$ & 23.48 & $10.05 \pm 0.16$ & $8.35 \pm 0.20$ & -16.92 & $13.30 \pm 0.16$ & $11.90 \pm 0.28$ & -10.53 \\
\hline & 250 & $17.02 \pm 0.16$ & $20.70 \pm 0.51$ & 21.62 & $10.40 \pm 0.14$ & $8.93 \pm 0.22$ & -14.13 & $13.80 \pm 0.17$ & $12.70 \pm 0.31$ & -7.97 \\
\hline & 500 & $14.22 \pm 0.24$ & $15.80 \pm 0.45$ & 11.39 & $10.70 \pm 0.17$ & $9.46 \pm 0.27$ & -11.59 & $14.60 \pm 0.07$ & $13.70 \pm 0.39$ & -6.16 \\
\hline & 1000 & $14.58 \pm 0.13$ & $16.10 \pm 0.44$ & 10.43 & $9.86 \pm 0.09$ & $9.13 \pm 0.25$ & -7.43 & $14.10 \pm 0.20$ & $13.70 \pm 0.38$ & -2.84 \\
\hline
\end{tabular}

Note: NC-Negative control; PC-Positive control; MF-M. oleifera flower; ML-M. oleifera leaf; WBC-White blood Cell; RBC-Red blood cells; HGB-Haemoglobin

TABLE 3: EFFECT OF M. oleifera (Lam.) CRUDE EXTRACT IN HAEMATOCRIT AND PLATELET AMOUNT OF $P$. yoelii INFECTED SWISS ALBINO MICE

\begin{tabular}{|c|c|c|c|c|c|c|c|}
\hline \multirow[t]{2}{*}{ Treatment } & \multirow[t]{2}{*}{$\begin{array}{c}\text { Dose } \\
\text { (mg/kg/0.5 ml } \\
\text { of water) }\end{array}$} & \multicolumn{2}{|c|}{$\begin{array}{c}\text { HCT } \\
\% \\
(\text { mean } \pm S D)\end{array}$} & \multicolumn{3}{|c|}{$\begin{array}{c}\text { PTL } \\
10^{3} / \mu \mathrm{l} \\
\text { (mean } \pm \text { SD) }\end{array}$} & \multirow{2}{*}{$\frac{\text { \% change }}{---}$} \\
\hline & & d 0 & d 4 & -- & $\mathrm{d} 0$ & $\mathrm{~d} 4$ & \\
\hline \multirow{3}{*}{$\begin{array}{l}\mathrm{dH}_{2} \mathrm{O}(\mathrm{NC}) \\
\text { Artemether } \\
(\mathrm{PC})\end{array}$} & -- & $47.56 \pm 0.28$ & $42.84 \pm 1.05$ & -9.92 & $805 \pm 0.06$ & $505.8 \pm 12.39$ & -37.17 \\
\hline & 1.25 & $47.40 \pm 0.13$ & $46.35 \pm 1.28$ & -0.11 & $826.6 \pm 0.18$ & $777.8 \pm 51.83$ & -5.9 \\
\hline & 125 & $46.50 \pm 0.09$ & $43.80 \pm 2.13$ & -5.81 & $725 \pm 0.23$ & $480 \pm 32.56$ & -33.79 \\
\hline \multirow{3}{*}{ MF } & 250 & $46.70 \pm 0.15$ & $44.39 \pm 2.45$ & -4.95 & $621.66 \pm 0.16$ & $442.4 \pm 27.7$ & -28.84 \\
\hline & 500 & $45.60 \pm 0.30$ & $43.85 \pm 1.11$ & -3.84 & $735.8 \pm 0.24$ & $620.8 \pm 33.92$ & -15.63 \\
\hline & 1000 & $46.50 \pm 0.18$ & $45.63 \pm 1.15$ & -1.87 & $769 \pm 0.1$ & $660 \pm 16.7$ & -14.17 \\
\hline \multirow{4}{*}{$M L$} & 125 & $46.90 \pm 0.06$ & $43.59 \pm 1.03$ & -7.06 & $728 \pm 0.13$ & $442 \pm 10.46$ & -39.29 \\
\hline & 250 & $45.20 \pm 0.04$ & $42.58 \pm 1.04$ & -5.8 & $795 \pm 0.17$ & $570.2 \pm 13.97$ & -28.28 \\
\hline & 500 & $47.02 \pm 0.08$ & $44.65 \pm 1.26$ & -5.04 & $829.2 \pm 0.05$ & $628.4 \pm 17.77$ & -24.22 \\
\hline & 1000 & $46.50 \pm 0.14$ & $45.44 \pm 1.25$ & -2.28 & $784 \pm 0.07$ & $613 \pm 16.90$ & -21.81 \\
\hline
\end{tabular}

Note: NC-Negative control; PC-Positive control; MF-M. oleifera flower; ML-M. oleifera leaf; HCT-Haematocrit; PTL-Platelet

treated groups showed their effectiveness significantly $(\mathrm{p}<0.05)$ against malaria parasite in the form of percent of suppression. Highest efficacy of effectiveness were shown by extract of $M$. oleifera flower with $58.52 \%$ followed by $M$. oleifera leaves with $56.30 \%$ at the highest dose level $(1000 \mathrm{mg} / \mathrm{kg})$ on $\mathrm{d} 4$.

According to Deharo et al. and Munoz et al. the antiplasmodial efficacy of a plant extract can be classified into three groups-moderate, good and very good. If any extract shows percentage parasitemia suppression equal to or greater than $50 \%$ at the dose level of $500 \mathrm{mg} / \mathrm{kg}$ body weight, it is considered as moderate, $250 \mathrm{mg} / \mathrm{kg}$ body weight it's considered as good and at $100 \mathrm{mg} / \mathrm{kg}$ body weight it's considered as very good ${ }^{[10,11]}$. Hence, according to current research, $M$. oleifera flower and M. oleifera leaves have moderate anti-plasmodium activity; as they showed 55.56 and $54.07 \%$ parasitemia suppression, respectively at $500 \mathrm{mg} / \mathrm{kg}$ of body weight on $\mathrm{d}$ 4. A compound is considered as active when percent parasitemia suppression is found equal to $30 \%$ or more ${ }^{[12,13]}$, that also supports the outcome of the current research.

If we compare the percent of suppression of parasites of both flower and leaf extracts with standard drug 


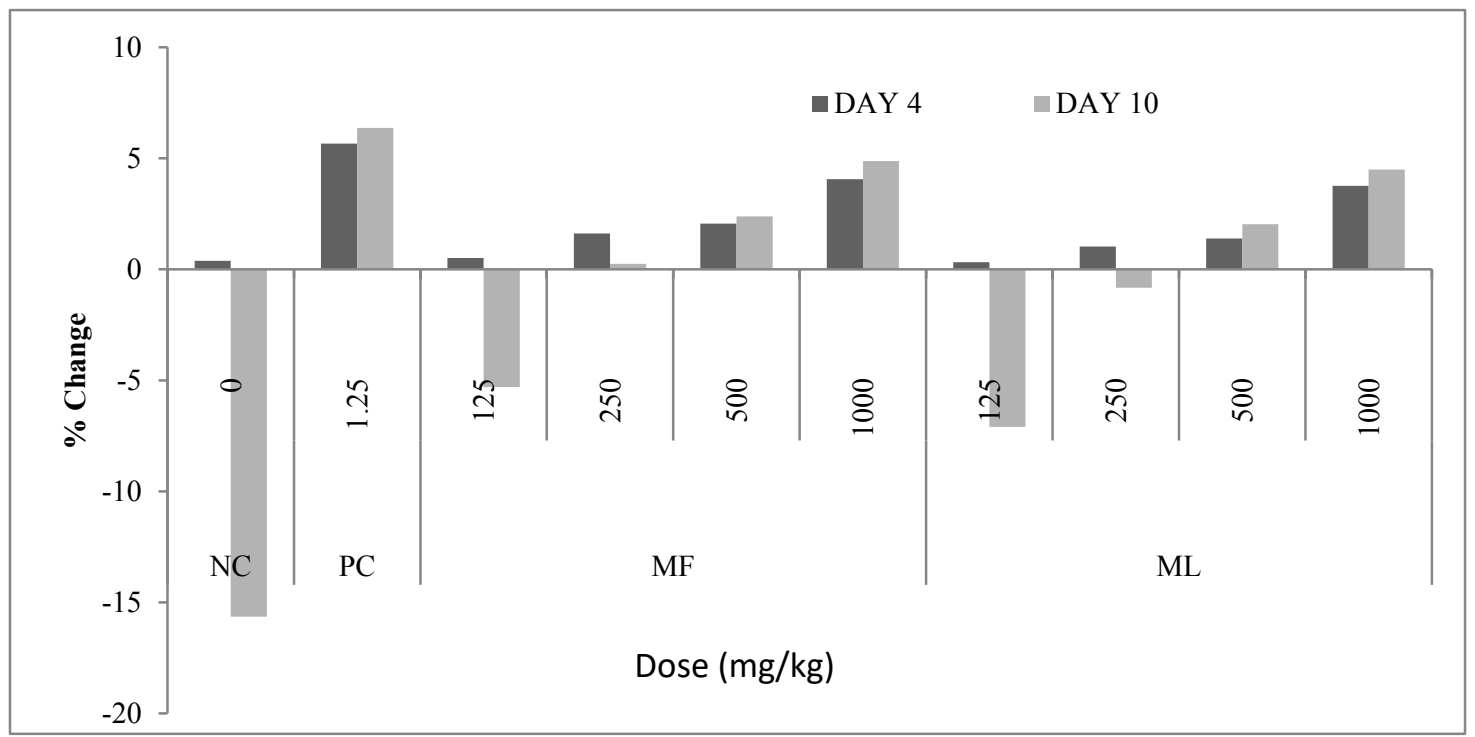

Fig. 2: Chemo-suppressive effect of $M$. oleifera (Lam.) crude extract on body weight of $P$. yoelii infected Swiss albino mice Note: NC-Negative control; PC-Positive control; MF-M. oleifera flower; ML-M. oleifera leaf; ( $\square$ ) d 4; ( $\square$ ) d 10

Artimether, it has been observed that both extracts are not as effective as standard drugs are, along with it has been also noticed that the chemo-suppressive efficacy of all plant extracts decrease, as the day progressed (Table 1).

Day to day observation during the post treatment period indicated the signs of the malaria infection which were seen in the all experimental mice because of regular rising of the parasitaemia. Succeeding growth of the parasitaemia in both extracts treated mice might indicate the effectiveness of the extracts remains for a short time due to their speedy breakdown or elimination by metabolism process $^{[14]}$.

M. oleifera plants have also been proved as powerful agents against different organisms like protozoa, bacteria and virus. Some previous studies indicated the medicinal efficacy of its different parts like leaf, stem, root, pods and seeds. A study was carried out to evaluate the antiprotozoal activity of $M$. oliefera against Leishmania donovani and revealed the parasite reduction significantly by using ethyl acetate fraction of $M$. oliefera flower by both assessment methods (i.e., in vivo and in vitro $)^{[15]}$. Similarly, in another study flower extract of the above plant showed activity against Trypanosoma cruzi by lysis of protozoan cell ${ }^{[16]}$.

Acetone extract of $M$. oliefera leaves was tested against different bacteria i.e., Staphylococcus aureus, Enterobacter cloace, Proteus vulgaris, Escherichia coli and Micrococcus kristinae and exhibited the inhibition in colonies of above bacteria at $5 \mathrm{mg} / \mathrm{ml}$ concentration $^{[17]}$. M. oliefera also showed the inhibition activity on the replication of virus in the host cell, for this, alcoholic extract of leaves and stem bark were tested against equine herpes virus- 1 and proved as effective ${ }^{[18]}$. Similarly above plant has been also proven as potent inhibitor for the treatment of Human Immunodeficiency Virus (HIV) early infection ${ }^{[19]}$.

Some studies revealed that malaria parasites directly affect the blood parameters leading to haematological variations especially in the blood cells like RBCs, leukocytes and thrombocytes that are responsible for malaria pathogenesis ${ }^{[20-23]}$. Normally, Plasmodium infected persons are found to have lower concentration of haemoglobin and low count of platelets and RBCs significantly unlike to high count of neutrophil and monocytes as compared to non-infected persons ${ }^{[20,22-26]}$.

M. oleifera plant shows high efficacy to prevent the loss of RBC, haemoglobin and haematocrit value as compared to negative control. These results also indicated that the extract has the efficacy to stimulate erythropoietin hormone, released from the kidney, regulating the $\mathrm{RBC}$ production ${ }^{[27]}$. It was observed that the count of WBC decreases in the extract treated mice, indicating the reduction of parasites. On the d 4, the best results were shown by flower extract of M. oleifera followed by leaf extract for all haematological parameters. The minute increase in haematological values in treated mice, indicated the prevention from disease development ${ }^{[28-30]}$.

The findings of this study showed that $M$. oleifera flower and leaf has an antimalarial activity. Our study clearly demonstrated that the flowers are more active as compared to leaf. Flower extract has given significant results for all considered parameters such as percent 
of suppression of parasites, high survival period of mice and prevention of changes in haematological values and in body weight as compared to negative control. Study strongly recommends that more efforts should be undertaken in future to continue the bioassay guided fractionation to isolate and identify the active compounds of $M$. oleifera flower and leaf extracts that have been already proven as antimalarial agents in the current study.

\section{Acknowledgments:}

We are grateful to the Department of Zoology, College of Science Mohanlal Sukhadia University Udaipur, Rajasthan for providing the laboratory facility for this work. We are also thankful to UGC for financial support as UGC- BSR fellowship for our research work.

\section{Conflict of interests:}

The authors declared no conflicts of interest.

\section{REFERENCES}

1. Morton JF. The horseradish tree, Moringa pterygosperma (Moringaceae)-a boon to arid lands?. Econ Bot 1991;45(3):31833.

2. Anwar F, Latif S, Ashraf M, Gilani AH. Moringa oleifera: a food plant with multiple medicinal uses. Phytother Res 2007;21:17-25.

3. Oecd TN. 425: Acute Oral Toxicity: Up-and-Down Procedure. OECD Guidelines for the Testing of Chemicals, Section 2008;4:1-27.

4. Knight DJ, Peters W. The antimalarial activity of N-benzyloxydihydrotriazines: I. The activity of clociguanil (BRL 50216) against rodent malaria and studies on its mode of action. Ann Trop Med Parasitol 1980;74(4):393-404.

5. Fidock DA, Rosenthal PJ, Croft SL, Brun R, Nwaka S. Antimalarial drug discovery: efficacy models for compound screening. Nat Rev Drug Discov 2004;3(6):509-20.

6. Nagendrappa PB, Franetich JF, Gay F, Lorthiois A, Venkatasubramanian P, Mazier D. Antiplasmodial activity of traditional polyherbal remedy from Odisha, India: Their potential for prophylactic use. Asian Pac J Trop Biomed 2015;5(12):982-6.

7. Murithi KC, Fidahusein DS, Nguta JM, Lukhoba CW. Antimalarial activity and in vivo toxicity of selected medicinal plants naturalised in Kenya. Int J Educ Res 2014;2(5):395-406.

8. Aherne SA, Daly $\mathrm{T}$, O'Connor $\mathrm{T}$, O'Brien NM. Immunomodulatory effects of $\beta$-sitosterol on human Jurkat $\mathrm{T}$ cells. Planta Med 2007;73(09):797-1034.

9. Ryley JF, Peters W. The antimalarial activity of some quinolone esters. Ann Trop Med Parasitol 1970;64(2):209-22.

10. Deharo E, Bourdy G, Quenevo C, Munoz V, Ruiz G, Sauvain M. A search for natural bioactive compounds in Bolivia through a multidisciplinary approach. Part V. Evaluation of the antimalarial activity of plants used by the Tacana Indians. J Ethnopharmacol 2001;77(1):91-8.

11. Muñoz V, Sauvain M, Bourdy G, Callapa J, Bergeron S, Rojas I, et al. A search for natural bioactive compounds in Bolivia through a multidisciplinary approach: Part I. Evaluation of the antimalarial activity of plants used by the Chacobo Indians. J Ethnopharmacol 2000;69(2):127-37.

12. Krettli AU, Adebayo JO, Krettli LG. Testing of natural products and synthetic molecules aiming at new antimalarials. Curr Drug Targets 2009;10(3):261-70.

13. Adugna M, Feyera T, Taddese W, Admasu P. In vivo antimalarial activity of crude extract of aerial part of Artemisia abyssinica against Plasmodium berghei in mice. Global $\mathrm{J}$ Pharmacol 2014;8(3):460-8.

14. Waako PJ, Gumede B, Smith P, Folb PI. The in vitro and in vivo antimalarial activity of Cardiospermum halicacabum $\mathrm{L}$. and Momordica foetida Schumch. Et Thonn. J Ethnopharmacol 2005;99(1):137-43.

15. Singh MK, Paul J, De T, Chakraborti T. Bioactivity guided fractionation of Moringa oleifera Lam. flower targeting Leishmania donovani. Indian J Exp Biol 2015;53:747-52.

16. Pontual EV, Pires-Neto DF, Fraige K, Higino TM, Carvalho $\mathrm{BE}$, Alves NM, et al. A trypsin inhibitor from Moringa oleifera flower extract is cytotoxic to Trypanosoma cruzi with high selectivity over mammalian cells. Nat Prod Res 2018;32(24):2940-4.

17. Moyo B, Masika PJ, Muchenje V. Antimicrobial activities of Moringa oleifera Lam leaf extracts. Afr J Biotechnol 2012;11(11):2797-802.

18. Virmani M, Garg SL. In vitro antiviral activity of plant extracts against equine herpes virus-1. Indian J Comp Microbiol Immunol Infect Dis 2005;26(2):89-91.

19. Nworu CS, Okoye EL, Ezeifeka GO, Esimone CO. Extracts of Moringa oleifera Lam. showing inhibitory activity against early steps in the infectivity of HIV-1 lentiviral particles in a viral vector-based screening. Afr J Biotechnol 2013;12(30):486673.

20. Bakhubaira S. Hematological parameters in severe complicated Plasmodium falciparum malaria among adults in Aden. Turk J Haematol 2013;30(4):394-9.

21. van Wolfswinkel ME, Vliegenthart-Jongbloed $\mathrm{K}$, de Mendonça Melo M, Wever PC, McCall MB, Koelewijn R, et al. Predictive value of lymphocytopenia and the neutrophillymphocyte count ratio for severe imported malaria. Malar J 2013;12(1):1-8.

22. Warimwe GM, Murungi LM, Kamuyu G, Nyangweso GM, Wambua J, Naranbhai $\mathrm{V}$, et al. The ratio of monocytes to lymphocytes in peripheral blood correlates with increased susceptibility to clinical malaria in Kenyan children. PLoS One 2013;8(2):e57320.

23. Maina RN, Walsh D, Gaddy C, Hongo G, Waitumbi J, Otieno L, et al. Impact of Plasmodium falciparum infection on haematological parameters in children living in Western Kenya. Malar J 2010;9(3):1.

24. Adedapo AD, Falade CO, Kotila RT, Ademowo GO. Age as a risk factor for thrombocytopenia and anaemia in children treated for acute uncomplicated falciparum malaria. J Vector Borne Dis 2007;44(4):266.

25. Erhart LM, Yingyuen K, Chuanak N, Buathong N, Laoboonchai A, Miller RS, et al. Hematologic and clinical indices of malaria in a semi-immune population of western Thailand. Am J Trop Med Hyg 2004;70(1):8-14.

26. Gérardin P, Rogier C, Amadou SK, Jouvencel P, Brousse V, Imbert P. Prognostic value of thrombocytopenia in African children with falciparum malaria. Am J Trop Med Hyg 2002;66(6):686-91.

27. Polenakovic M, Sikole A. Is erythropoietin a survival factor 
for red blood cells?. J Am Soc Nephrol 1996;7(8):1178-82.

28. Chang KH, Stevenson MM. Malarial anaemia: mechanisms and implications of insufficient erythropoiesis during bloodstage malaria. Int J Parasitol 2004;34(13-14):1501-16.

29. Weatherall DJ, Miller LH, Baruch DI, Marsh K, Doumbo
OK, Casals-Pascual C, et al. Malaria and the red cell. Am Soc Hematol Educ Program Book 2002;2002(1):35-57.

30. Piguet PF, Kan CD, Vesin C. Thrombocytopenia in an animal model of malaria is associated with an increased caspasemediated death of thrombocytes. Apoptosis 2002;7(2):91-8. 